\title{
"Eu e meus alunos-cotistas na escola pública": racismo, ethos discursivo, discurso midiático e produção de subjetividade ${ }^{1}$
}

\author{
"Me and my quota student in public school": racism, discursive ethos, \\ media discourse and subjectivity production
}

\author{
Bianca Assis Oliveira de Paula ${ }^{1}$ \\ Fabio Sampaio de Almeida $\oplus^{2}$ \\ Maria Cristina Giorgi $\odot^{2}$ \\ ${ }^{1}$ Secretaria Municipal de Educação (SME), Rio de Janeiro, Rio de Janeiro, Brasil \\ ${ }^{2}$ Centro Federal de Educação Tecnológica Celso Suckow da Fonseca (Cefet/RJ), Rio de Janeiro, Rio de Janeiro, Brasil.
}

$$
\diamond
$$

\begin{abstract}
RESUMO
Nosso objetivo, neste artigo, é propor uma análise discursiva de texto produzido por docente do Cefet/RJ, que deflagrou polêmica nas redes sociais. O depoimento da professora, que viralizou nas redes sociais, sobre experiência com alunos cotistas do Ensino Médio, em um primeiro momento, foi acolhido como um relato emocionado e emocionante, resultado de postura "empática e generosa". Posteriormente, entretanto, ao ser 'republicado', passou a ser lido como fruto do racismo estruturante que organiza as relações sociais no país e sua autora vista como uma pessoa racista. Com foco na materialidade do discurso e seus efeitos de produção de subjetividade e em uma dada qualidade de real(idade) (ROCHA, 2006), buscamos problematizar sentidos que se constroem, na contemporaneidade, a partir da tensão entre discursos racistas e antirracistas, na construção de um ethos (MAINGUENEAU, 1997, 2006, 2006,2008 ) de professora que aponta para uma figura que surge para salvar os alunos cotistas - que são necessariamente negros segundo o senso comum - numa evidente visão de mundo racista, que opõe professora e alunos aos 'cotistas'.
\end{abstract}

Palavras-chave: Ethos. Racismo. Mídia. Alunos-cotistas. Cefet/RJ.

\begin{abstract}
The aim of this paper is to propose a discursive analysis of a text produced by a teacher who works at Cefet/RJ, that triggered controversy in social networks. The testimony of the teacher, which went viral on social networks, was about her experience with high school quota students. It was initially welcomed as an emotional and touching report and as the result of an "empathic and generous" attitude. Later, however, when it was 'republished', it came to be read as the result of the structuring racism that organizes social relations in Brazil. Besides that, its author came to be regarded as a racist person. By focusing on the materiality of discourse and its effects of subjectivity production and on a given quality of real(ity) (ROCHA, 2006), we seek to problematize meanings that are built on the tension between racist and antiracist discourses in contemporaneity in the construction of an ethos (MAINGUENEAU, 1997, 2006, 2006, 2008) of a teacher who points to a figure that emerges to save the quota students - who are necessarily black according to common sense - in an evident racist world view that opposes teacher and students to 'quota students'.
\end{abstract}

Keywords: Ethos. Racism. Media. Quota students. Cefet/RJ.

Nota SOBRE O ARTIGO: O artigo "Eu e meus alunos-cotistas na escola pública": racismo, ethos
discursivo, discurso midiático e produção de subjetividade, DOI: http://dx.doi.org/10.15448/1984-
7726.2018 .3 .30988 , foi publicado originalmente na revista Letras de Hoje, v. 53, n.3, jul.-set. 2018,
DOI: http://dx.doi.org/10.15448/1984-7726.2018.3.

Este artigo é resultado de discussões realizadas no grupo de pesquisa Práticas discursivas na produção de identidades sociais: Fatores humanos, organizações, trabalho, tecnologia e sociedade (PRADISIS), que têm como um de seus focos principais questões de racismo em ambientes escolares, do qual fazem parte os três autores. 


\section{Considerações iniciais}

No ano de 2016, uma professora do Centro Federal de Educação Tecnológica do Rio de Janeiro (Cefet/RJ) produziu um texto sobre sua experiência com alunos cotistas do Ensino Médio da instituição, que viralizou nas redes sociais. Publicado no Facebook ${ }^{2}$, o depoimento, que chegou a ser compartilhado por cerca de 15 mil pessoas e curtido por mais de $31 \mathrm{mil}^{3}$, gerou muitos outros textos, dentre os quais se destacaram os comentários na própria rede social, daqueles que o liam como um relato emocionado e emocionante, resultante de uma postura "empática e generosa".

Passado um ano, a autora 'republica' o texto, que, novamente, teve grande repercussão. No entanto, no novo momento de circulação, a relação estabelecida entre os modos de difusão e de consumo (MAINGUENEAU, 2008) desse texto já não são as mesmas e algumas das reações a ele são bastante distintas das iniciais. O depoimento começou a ser visto como resultado do racismo estruturante que organiza as relações sociais no país, e sua autora, como uma pessoa racista. As mídias tradicionais e as redes sociais se dividiram, uns defendendo outros atacando a professora. Fala-se em linchamento virtual, com investidas à autora que, após se explicar em outro texto ${ }^{4}$, abandona as redes sociais - por algum tempo.

Considerando, portanto os contextos de produção e circulação do texto e as questões étnico-raciais, temos como problema orientador da pesquisa a seguinte questão: de que modo se constrói o ethos discursivo do enunciador na referida publicação? Para responder a tal questão, propomos como objetivo geral, neste artigo, uma análise discursiva do texto que deu origem à polêmica ora descrita, de modo a problematizar sentidos que se constroem na tensão entre discursos racistas e antirracistas na contemporaneidade.

Dessa forma, como analistas do discurso - longe de 'descortinar intenções' por trás do texto, ou avaliar o trabalho de uma professora e qualificar sua relação pessoal afetiva com seus alunos -, nosso foco recai sobre a materialidade do discurso e seus efeitos de produção de subjetividade e em uma dada qualidade de real(idade) (ROCHA, 2006).

Para tal, explicitamos nosso locus de enunciação, constitutivo do processo de produção de subjetividade que envolve a pesquisa acadêmica de modo geral, e a pesquisa

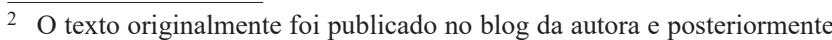
compartilhado no Facebook. Após a repercussão negativa, em 2017, o texto foi retirado das redes sociais da autora.

3 Informações disponíveis em: http://blogdovalente.com.br/noticias/ educacao/2016/05/professora-faz-relato-emocionante-sobre-alunoscotistas-e-post-viraliza/

4 https://elikatakimoto.com/2017/05/03/ate-um-dia-facebook/
}

orientada por uma Linguística Aplicada Indisciplinar (MOITA LOPES, 2006), em específico. Falamos do lugar de pesquisadores e professores engajados na luta antirracista, oriundos das classes populares, cujas histórias familiares remontam a lugares sociais de menor prestígio. E assim, ao participar dos debates promovidos e provocados pelo o referido texto, compreendemos, como Foucault (2009, p. 10), que “o discurso não é simplesmente aquilo que traduz as lutas ou os sistemas de dominação, mas aquilo por que, pelo que se luta, o poder do qual nos queremos apoderar". Assim, analisar as fricções entre discursos racistas e antirracistas, no âmbito das políticas de ações afirmativas, além de produzir conhecimentos contingentes, constitui um fazer político e ético, tal qual entende Moita Lopes (2009).

Nosso artigo está dividido em quatro seções. $\mathrm{Na}$ primeira seção, discutimos acerca da relevância das cotas como política de ação afirmativa que amplia o acesso à educação pública superior e médio/técnica a sujeitos historicamente excluídos e da tensão entre discursos racistas e antirracistas. Na segunda, apresentamos o referencial que sustenta a concepção de ethos, discurso e sentido que fundamenta nossas análises. Na seguinte, discutimos as análises discursivas do texto e, por último, apresentamos nossas considerações finais.

\section{As cotas raciais na tensão entre discursos racistas e antirracistas}

Como é sabido, a política de cotas raciais no Brasil surgiu como conquista das lutas dos movimentos negros no empenho para que a representação da diversidade racial presente na sociedade brasileira estivesse em todos os espaços institucionais, e principalmente pela reparação histórica das condições de exclusão das pessoas negras das universidades, da política e dos cargos públicos, garantindo percentuais de vagas em concursos e processos seletivos amplos.

Em consonância com essa política, em 2012, a legislação federal institui a obrigatoriedade da entrada de alunos oriundos de escolas públicas, baixa renda e negros, através da política de cotas para os institutos federais e instituições cognatas, como o Cefet/RJ, - instituição pública e gratuita de formação técnica desde 1917 - que, atualmente, oferece cursos de formação profissional de nível médio, de graduação, de mestrado e doutorado.

A partir de então, como já ocorrido com a implementação do sistema de cotas nas instituições de Ensino Superior, passam a circular entre os professores e parte dos alunos ingressantes pela ampla concorrência, discursos que apostam em uma "queda na qualidade do ensino de excelência" do Cefet/RJ a partir da entrada dos chamados "cotistas". 
Faz-se necessária aqui uma observação. Ainda que em nenhum momento a autora do depoimento especifique que trata de cotas raciais, há uma associação naturalizada entre cotistas e negros, que se justifica porque se nem todas as cotas são raciais elas têm como função abrir caminho para grupos excluídos, e os negros são, certamente, parte significativa desses grupos. Tal associação constrói-se com base numa lógica racista, na qual a relação entre grupos etnicamente marcados, principalmente por seu fenótipo, em nossa sociedade, se organiza em torno de discursos e práticas hierarquizantes e produtoras de desigualdades, seja com relação à classe social, à origem geográfica, às atividades profissionais dentre outras diferenças. Partindo dessa compreensão, Guimarães (2009, p. 36) explica que há casos em que,

(...) o preconceito e a discriminação pressupõem ou se referem à ideia de 'raça' de maneira central. Nestes, as demais diferenças são imagens figuradas de 'raça'. São casos em que a hierarquia social não poderia manter um padrão discriminatório sem as diferenças raciais.

No caso do Cefet/RJ, por exemplo, a distribuição de cotas se dá da seguinte forma: C1 - ampla concorrência; $\mathrm{C} 2$ - alunos que cursaram o ensino fundamental em escola pública; C3 - alunos que cursaram o ensino fundamental em escola pública e autodeclaração de pretos, pardos ou indígenas; $\mathrm{C} 4$ - alunos que cursaram o ensino fundamental em escola pública e renda per capita inferior a 1,5 salário mínimo; C5 - alunos que cursaram o ensino fundamental em escola pública e autodeclaração de pretos, pardos ou indígenas e com renda per capita inferior a 1,5 salário mínimo. Portanto, no contexto do estado do Rio de Janeiro, os critérios que incluem classe social somam-se ao quesito raça na construção do perfil desse aluno dito cotista, alvo dessas políticas afirmativas.

Segundo Munanga (2001, p. 31), as referidas políticas têm como objetivo "oferecer aos grupos discriminados e excluídos um tratamento diferenciado para compensar as desvantagens devidas à sua situação de vítimas do racismo e de outras formas de discriminação", sendo primordial que haja reconhecimento social de tais desvantagens e especificamente do racismo que as produz. De modo oposto, o tema continua sendo bastante polêmico e controvertido, sendo alguns dos principais argumentos já problematizados e desconstruídos por movimentos sociais e trabalhos acadêmicos (MUNANGA, 2001; PIOVESAN, 2008; SANTOS, 2012; GUIMARÃES; RIOS, 2014) -, para fundamentar discursos contrários às cotas raciais são: 1) a "racialização" da sociedade brasileira, produzindo uma diferença, supostamente não existente, entre brancos e negros; 2) a "violação" de direitos de igualdade ao, supostamente, se favorecer negros em detrimento de outros grupos, como brancos pobres, por exemplo; 3) a negação do "mérito" individual como critério de ascensão social.

Do ponto de vista discursivo, os argumentos apresentados se organizam a partir de um sistema de restrições semânticas que constitui uma prática discursiva (MAINGUENEAU, 2008), "racista não assumida", uma vez que nega sistematicamente a existência de uma desigualdade racial, que não seja produzida ela mesma pelos próprios sujeitos negros. É o "racismo à brasileira", que, como explica o antropólogo Roberto da Matta (1997) tem sua manifestação de modo implícito, disfarçado e de difícil discussão, constituindo de modo geral um tabu entre os brasileiros.

Nesse sentido, a produção de um discurso anti-cotas, assumido ou não como racista, concretiza o que afirma Munanga (2001, p. 32), ao dizer que "qualquer proposta de mudança em benefício dos excluídos jamais receberia um apoio unânime, sobretudo quando se trata de uma sociedade racista".

Refletindo teoricamente sobre a relação entre discurso e desigualdade social, é preciso considerar que ainda que o discurso possibilite que "as mesmas palavras" ou posições discursivas sejam assumidas por sujeitos inscritos em diferentes formações discursivas com aparente similitude, não se pode ignorar que na produção de "diferenças sociais", como as de raça e gênero, há uma assimetria fundamental construída historicamente, pois as condições de produção não são as mesmas. Os processos sociais, históricos e discursivos de formação de um discurso hegemônico racista e machista não são facilmente reconstruídos em outras bases. Portanto, é inaceitável a ideia de um racismo reverso ou de o feminismo ser um machismo ao contrário, visto que, tanto o discurso antirracista quanto o feminista só existem em contraposição a discursos anteriores, racistas e machistas que, de modo amplo, se legitimaram e naturalizaram em nossa cultura.

E é a naturalização de tais discursos que os tornam difíceis de serem desconstruídos, pois não se assumem como discursos segregadores. No entanto, acreditamos que a análise do discurso pode contribuir para essa desnaturalização, uma vez que seja possível identificar marcas linguístico-discursivas que possibilitem expor práticas racistas, machistas, homofóbicas, dentre outras práticas que ferem os direitos humanos.

\section{Ethos, discurso e análise do discurso como caminhos para pensar a tensão entre racismo e antirracismo}

É possível afirmar que as análises do discurso, de diferentes orientações teóricas, podem contribuir tanto como enquadre epistemológico que nos propicia 
compreender as condições de produção de um discurso racista, quanto como ferramenta que nos permite, pelo viés da análise da materialidade linguística, ter acesso a contradições, nos discursos "bem intencionados", e assim poder criar inteligibilidade e disputar sentidos, conforme a perspectiva foucaultiana referida na introdução deste texto.

Reiteramos que nossas análises buscam colocar em jogo pistas identificadas no texto, não no intuito de julgar quaisquer posicionamentos intencionais de sua autora por entendermos que:

a) no plano discursivo, o sujeito se produz simultaneamente à sua própria prática discursiva (MAINGUENEAU, 2008), isto é, o enunciador se constitui em sujeito do discurso ao enunciar, o que produz uma circularidade entre sujeitos e textos.

b) os discursos que proferimos estão sempre atravessados por outros discursos e discursos do Outro, que refletem as práticas discursivas na quais interagimos, as relações de saber e poder que constituem o campo social e uma memória discursiva a partir de processos de citação/ reiteração de outros textos.

c) o querer-dizer do locutor, nos termos de Bakhtin (2000), restringe-se à escolha de um gênero de discurso. O caso por nós analisado, um depoimento em uma rede social tem por objetivo fazer circular determinadas narrativas e posicionamentos, atingindo o maior número de pessoas, pelos mecanismos de compartilhamento e curtidas.

Não queremos dizer com isso que ao produzir discursos não há qualquer intervenção de uma dimensão intencional, nem tampouco alegar um assujeitamento total daquele que enuncia. Todavia, reafirmamos que nossa pretensão com a análise proposta é iluminar os atravessamentos e o modo como a linguagem - longe de ser uma simples representação do real - produz intervenções e invenções (ROCHA, 2006), construindo a própria realidade, fazendo aparecer determinados sujeitos - nesse caso sujeitos racializados - e objetos, como afirma Foucault (2008).

Tomamos aqui a noção de raça entendida como construto sociodiscursivo (HALL, 2015), uma ficção útil produzida sobre um outro, construída historicamente pelo europeu ao deparar-se com o africano. A partir daí a raça passa a funcionar como um dos grandes sistemas de exclusão produzidos pela humanidade que segue operando em relações de poder, mesmo depois de as ciências negarem sua existência biológica. O racismo, tomado como prática social e discursiva, produz um outro que não é semelhante ao sujeito hegemônico, mas um objeto a ser eliminado simbólica ou concretamente, por ser essencializado discursivamente como ameaçador, cuja construção é designada pelo cientista político e filósofo camaronês Achile Mbembe (2014) por meio do termo "alterocídio".

A construção do eu e do outro na linguagem pode ser estudada no contexto da enunciação. De acordo com Maingueneau (1997, 2013), por sua própria enunciação, todo texto encarna as propriedades comumente associadas ao caráter e à corporalidade de um sujeito produzido discursivamente a partir de representações coletivas, isto é, de um estereótipo que circula no imaginário social, sendo a categoria que dá visibilidade a esse sujeito o ethos discursivo, noção oriunda da retórica filosófica.

\begin{abstract}
Quanto à 'corporalidade', ela é associada a uma compleição corporal, mas também a uma forma de vestir-se e de mover-se no espaço social. O ethos implica assim um controle tácito do corpo, apreendido por meio de um comportamento global. Caráter e corporalidade do fiador apóiam-se, então, sobre um conjunto difuso de representações sociais valorizadas e desvalorizadas, de estereótipos sobre os quais a enunciação se apóia e, por sua vez, contribui para reforçar ou transformar. Esses estereótipos circulam nos registros mais diversos da produção semiótica de uma coletividade: livros de moral, teatro, pintura, escultura, cinema, publicidade... (MAINGUENEAU, 2005, p. 72).
\end{abstract}

No entanto, o linguista francês explica que ao ser atualizado pela análise do discurso, o ethos retórico realiza um duplo afastamento: a) de qualquer visão "psicologizante" e "voluntarista" do enunciador, dado que se esse sujeito não possui controle sobre os efeitos que produz em seu discurso sobre um dado coenunciador, tais efeitos são impostos pela constituição com certas restrições semânticas do próprio discurso; b) de uma visão redutora de interação, já que, independentemente de se oral ou escrito, todo texto é sustentado por uma voz que se integra a um corpo.

Nesse sentido, a noção de ethos, na perspectiva de Maingueneau (1997), possibilita o estudo da(s) instância(s) subjetiva(s) envolvida(s) na enunciação, visto que é pelo próprio ato de enunciar que o enunciador constrói a legitimidade de sua enunciação, produzindo uma representação de si que o coenunciador associa a um caráter e uma corporalidade. Ou seja, pode-se afirmar que a maneira de dizer - chamada pelo autor de tom, que vale tanto para textos orais quanto escritos - revela uma maneira de ser desse enunciador, porque constitui "um ideal de entonação que acompanha seus lugares de enunciação" (MAINGUENEAU, 1997, p.46).

Do ponto de vista discursivo assumido neste texto, faz-se necessário explicitar que o ethos construído pelo texto-depoimento nas redes sociais na figura de um 
enunciador encarnado não coincide necessariamente com uma pessoa empírica que enuncia o texto, mas se refere a uma entidade discursiva que se institui por intermédio da própria enunciação. A noção de ethos então permite identificar esse ser de discurso pelas características que demonstra, marcadas na textualidade, tais como o vocabulário, a intertextualidade, a construção composicional etc.

O ethos não é uma característica inerente e exclusiva do enunciador; o coenunciador, por intermédio de um processo designado incorporação, (MAINGUENEAU, 1997, 2013) assimila também o ethos, pela interação com o fiador, instância subjetiva que se coloca como fonte do dito.

Ao fiador, cuja figura o leitor deve construir a partir de indícios textuais de diversas ordens, são atribuídos um caráter e uma corporalidade, cujo grau de precisão varia entre os textos. O 'caráter' corresponde a uma gama de traços psicológicos. Já a 'corporalidade' corresponde a uma compleição corporal, mas também a uma maneira de se vestir e de se movimentar no espaço social. (MAINGUENEAU, 2013, p. 109)

Assim, a incorporação atua sobre três registros indissociáveis e complementares: 1) a enunciação dá corpo ao enunciador, levando o coenunciador a construir um ethos para o fiador do discurso; 2) o coenunciador, consequentemente, incorpora e assimila um conjunto de esquemas que definem uma forma específica de se inscrever no mundo para um dado sujeito, pela maneira de controlar e habitar seu corpo; 3 ) o coenunciador passa a congregar um corpo, "o da comunidade imaginária dos que comungam na adesão de um mesmo discurso" (MAINGUENEAU, 2013, p. 109). Desse modo, "Além da persuasão por argumentos, a noção de ethos permite de fato, refletir sobre o processo mais geral da adesão de sujeitos a certa posição discursiva" (MAINGUENEAU, 2005, p. 69). Compreende-se, portanto, que o ethos se configura por um paradoxo constitutivo, pois é por meio de seu próprio enunciado que o enunciador deve legitimar sua maneira de dizer, não sendo possível dissociar a organização dos conteúdos e a legitimação da cena de fala. Desse modo, a palavra vem de alguém que pela enunciação demonstra possuir as qualidades que evoca, provocando assim a adesão dos leitores que compõem esse tipo de público.

No texto em análise, parece-nos evidente o deslocamento das condições de emprego na produção de sentidos e de um ethos para o enunciador, uma vez que, em dois momentos distintos de circulação, o mesmo foi recebido de modo diferente por diferentes coenunciadores, os quais enfatizam por um lado um ethos de empatia, generosidade e salvação e por outro, um ethos racista, como discutimos no próximo, item em que procedemos às análises do texto.

\section{"levei um susto ao entrar em sala": análise discursiva de um ethos racista}

A escolha do gênero discursivo depoimento em redes sociais ${ }^{5}$ implica um certo modo de circulação e recepção do texto. O relato da autora, figura pública com evidente posicionamento político, destina-se, de modo geral, a seus seguidores e constitui, a nosso ver, uma história de "superação pessoal", no que tange à aceitação de alunos cotistas, no papel de professora de uma instituição pública federal que possui tradição e reconhecimento na formação de nível médio/técnico.

O texto-depoimento constrói uma cena marcada por uma topografia: a instituição escolar Cefet/RJ de modo geral e, mais especificamente, o espaço da sala de aula, e uma cronografia que se desdobra em dois tempos: 1) "Há quatro anos" - momento em que entraram os primeiros alunos cotistas na instituição - e 2) "Este ano" - momento em que o texto é escrito e no qual se ancoram as marcas temporais. A divisão da narrativa em dois tempos acaba por mostrar uma ruptura, um antes e um depois, uma transição na própria trajetória da professora, que dialoga com o que chamamos de história de superação pessoal.

Com relação aos seus coenunciadores, entendemos que podem ser chamados de seguidores, visto que a postagem original do texto foi feita no blog da autora, gênero que, de acordo com Komesu (2005, p. 198) pressupõe "um modo de enunciação fundado na publicização de si na relação com a intimidade construída entre enunciador e co-enunciador". A partir do blog, o texto foi postado na rede social Facebook, o que permitiu sua difusão por meio de compartilhamentos, leitura e reações por outros leitores para além do coenunciador construído. Após a repercussão negativa em 2017, o texto foi retirado das redes sociais da autora, estando atualmente disponível apenas em blogs e sites de notícias.

Como categorias organizadoras da análise, destacamos sentidos produzidos pelo enunciador-professora, instância que se coloca como fiador do discurso, a respeito de três sujeitos construídos na narrativa do texto: a professora e o aluno regular, por um lado, e o aluno cotista, por outro. Esses três sujeitos são mobilizados, inicialmente, para a construção de uma imagem de si o ethos - que é corroborada por uma imagem do outro, especificamente o aluno cotista.

Recorrer a enunciados implícitos no texto em questão mostrou-se muito proveitoso visto que a autora, a nosso

\footnotetext{
Os excertos usados na análise e disponibilizados neste artigo foram obtidos pelo recurso de salvar (printar) as telas do smartphone, realizado por uma das autoras do artigo em 02 de maio de 2016, às 18:11h.
} 
ver, ao apresentar seu próprio ponto de vista não se dá conta da polêmica relação que instaura a partir da recusa de um outro ponto de vista, ou do ponto de vista de um outro. Ducrot (1977) descreve duas categorias de implícitos: o pressuposto e o subentendido, definindo o primeiro como um ato e o segundo como a maneira pela qual o sentido deve ser decifrado pelo destinatário. Os subentendidos relacionam-se ao que pode concluir o interlocutor a partir do dito. Já os pressupostos são as descrições que se pode fazer a partir dos componentes linguísticos do enunciado. Em oposição aos subentendidos, pode-se afirmar que os pressupostos são parte do sentido material do enunciado enquanto os subentendidos relacionam-se a um interdiscurso de responsabilidade do interlocutor. Vejamos a análise do excerto 1, a seguir.

\section{Excerto 1}

Há quatro anos, tivemos no CEFET/RJ nossos
primeiros alunos cotistas. Para entrar lá, os jovens
fazem uma prova de seleção. Naquele ano, $50 \%$ das
vagas foram destinadas para alunos negros, de
escolas públicas e com renda baixa.
Lembro-me que levei um susto ao entrar em sala.
Havia negros e alunos extremamente diferentes na
forma de se expressar. Eu simplesmente não sabia
como lidar. Pensei em escrever uma carta para Dilma
reclamando. Se esse governo quer colocar cotistas
em sala, que ao menos nos dê uma certa infra-
estrutura para recebê-los! Psicólogos, pedagogos,
assistentes sociais... cadê esse time para nos ajudar?
Nada? Como assim?

Fonte: Print de texto postado no Facebook no dia 30/04/2016 às $14: 27 \mathrm{~h}$

O enunciador-professora relata um "susto ao entrar em sala (porque) havia negros e alunos extremamente diferentes na forma de se expressar". Primeiramente, causa estranheza o fato de uma docente conseguir perceber, já "ao entrar em sala", a diferença no modo de se expressar dos alunos. Em seguida, as designações "negros e alunos", colocadas paralelamente, apontam para um dado posicionamento que exclui os negros da posição de alunos. O "negro" aqui serve como designação que nomeia o outro sobre o qual se vai falar ao longo do texto, configurando um elemento de alteridade marcado corporalmente que, por oposição, corrobora a construção de um ethos branco, superior, como veremos na sequência da análise.

Sobre o uso da designação negro, Mbembe (2014) pontua que a construção de sentidos sobre esse substantivo, que embora tenha origens gregas, árabes, egípcias e até chinesas, enraiza-se, discursivamente, na Idade Moderna, por meio das narrativas de viajantes, missionários, aventureiros e colonos, como produto de uma 'ciência colonial' que põe o africano no patamar mais baixo. Nomeado por Mbembe como "razão negra", seria este um sistema de narrativas, discursos e práticas pretensamente conhecedores e fornecedores de álibis para a dominação de raças ditas inferiores. Dialogando com Maingueneau (2008), podemos pensar que o temos negro carrega em sua memória discursiva uma semântica global do racismo colonial, com suas próprias restrições constituídas historicamente.

Voltando ao fragmento anterior do depoimento (Excerto 1), dialogando com possíveis subentendidos, pode-se questionar: o que causaria tamanho estranhamento "na forma de se expressar"? Quais seriam essas formas de se expressar que não causariam estranhamento em uma cidade que se apresenta diversa e multicultural como o Rio de Janeiro, visto que a docente as classifica com a designação "extremamente diferentes"? Diferentes de quem? Iguais a quem?

Talvez, mas que devido à forma de se expressar, o estranhamento tenha sido causado pela ideia - um discurso naturalizado - que cada um de nós tem, mesmo sem ter consciência, de quem pode e deve ocupar cada espaço social. Se, como já dito antes, a maioria dos alunos que ingressa por cotas é negra, um aumento do número de alunos negros em sala contraria, dentro de uma sociedade racista como a nossa, o entendimento de quais lugares esse negro deve ou pode ocupar, pois esse é o lugar simbólico de branquitude ${ }^{6}$ - naturalizada como não-raça. Cabe lembrar que, embora com uma base em características físicas visíveis, visto que o fenótipo é a manifestação dos genes, a construção da negritude, assim como a da branquitude, é sempre social, histórica e discursiva. E, no Brasil, onde o foco do racismo é a aparência externa, e a identificação de traços mais ou menos europeus, o ser "branco" garante privilégios sociais, como o ocupar uma escola como o Cefet/Rj.

\section{Excerto 2}

$$
\begin{aligned}
& \text { Percebi que muitos não sabiam o que era "estudar" } \\
& \text { porque, meodeos, nunca haviam estudado. Era como } \\
& \text { eu virar para qualquer outro na rua que nunca, por } \\
& \text { exemplo, estudou música e falar: você tem que treinar } \\
& \text { piano! Você tem que treinar piano! O cara ia sentar em } \\
& \text { frente ao piano e fazer o quê? Não saberia nem por } \\
& \text { onde começar! Quando percebi isso entrei em } \\
& \text { desespero porque o problema era muito maior do que } \\
& \text { pensava... }
\end{aligned}
$$

Fonte: Print de texto postado no Facebook no dia 30/04/2016 às $14: 27 \mathrm{~h}$

\footnotetext{
6 De acordo com Schucman (2013, p. 26-27), "o contexto multirracial brasileiro propicia mediações bastante diferenciadas para a constituição de sujeitos e, portanto, para a subjetividade de brancos e não brancos. A marca dessa diferença e dessa desigualdade perpassa toda a socialização de tais indivíduos, na casa, na escola, na rua, e todos os espaços públicos são marcados pela supervalorização da branquitude e pela preferência do branco em relação ao não branco."
} 
Mesmo declarando que "não sabia como lidar" com esses alunos, com "forma de se expressar" tão peculiar, o enunciador-professora diz tentar seguir sua prática rotineira de mandar seus alunos estudarem. Mas em seguida, como consta no Excerto 2 afirma: "entrei em desespero" ao constatar que há um problema muito maior apontado no seguinte enunciado: "não sabiam o que era 'estudar' porque, meodeos, nunca haviam estudado". Uma simples análise contextual já possibilita problematizar tal argumentação, uma vez que se a crítica é à falta de domínio de dados conteúdos, isso não se refere a saber ou não estudar, tendo em vista que a seleção para ingresso na instituição continua sendo feita através de provas. Com reservas de cotas ou não, há ainda um processo seletivo concorrido se comparada a relação candidato-vaga. Nesse contexto, a comparação com a música, usada pelo enunciador-professora, constrói esse aluno cotista como aquele que não sabe nada pois nunca estudou, desqualificando todo um sistema de ensino que frequentou antes de chegar ao nível de escolaridade em questão. E o enunciador-professora vai construindo seu ethos, como aquela professora que passa a compreender as supostas dificuldades desses alunos e com elas se importa e responde emocionalmente. Entretanto, em seu relato ao desqualificar, por meio enunciados 'descritivos', esses alunos de modo tão explícito, não apenas tem como efeito ressaltar sua própria postura, mas também construirse como racista (cf. MBEMBE, 2014; GUIMARÃES, 2009), ao reforçar uma desigualdade social, tornando-a discursivamente exótica e produzindo/inventando, assim como coloca Rocha (2014), uma dada qualidade de real.

Excerto 3

O que fazer? Desistir? Deixar que todos repetissem? Mas seriam muitos! O desespero une os seres humanos que estão sob o mesmo inferno. Nós, professores, fomos conversando e juntamente com parte da equipe pedagógica, criando subsídios para esses alunos.

Fonte: Print de texto postado no Facebook no dia 30/04/2016 às $14: 27 \mathrm{~h}$

No Excerto 3, destacamos a dêixis enunciativa, que pelo uso da primeira pessoa do plural no enunciado deixa evidente outra oposição subentendida: a daqueles que criaram o inferno - os cotistas, devido à dificuldade de não saberem estudar - e aqueles convocados para salvar a situação - professores e parte da equipe pedagógica. Interessante, ainda, é notar que se a docente se alinha aos alunos não-cotistas, a outros professores, à equipe de pedagogos, psicólogos e assistentes sociais, em nenhum momento essa aliança, marcada pelo uso do dêitico nós ocorre entre ela e os alunos-cotistas.
Não negando a necessidade de políticas de permanência que complementem as políticas de acesso em qualquer instituição - recursos materiais e estruturais como transporte e alimentação -, no momento em que pedagogos, psicólogos e assistentes sociais são demanda apenas para o atendimento aos alunos cotistas, não se está criando uma associação automática entre estes e questões que pressuponham profissionais de área tão específica da saúde? Principalmente considerando que o atendimento psicológico no Cefet/RJ já era disponibilizado a servidores e discentes, antes da implementação do sistema de cotas.

Retomando o que já dissemos, o enunciadorprofessora constrói um perfil do cotista, como o de um aluno que se "expressa de forma diferente" (Excerto 1), que "não sabiam o que era 'estudar' porque, meodeos, nunca haviam estudado" (Excerto 2) e que pressupunham a necessidade do trabalho de especialistas como pedagogos, e psicólogos e assistentes sociais (Excerto 3). Todos enunciados descritivos que constroem esse outro, cotista, como inferior em uma hierarquia social.

Soma-se a essa construção a ideia de um aluno que chega ao Ensino Médio e que "mal sabia pegar no lápis por falta de hábito..." (Excerto 4). Além de não estudar, o cotista não escreve fora do âmbito da escola, não desenha, ou pratica quaisquer atividades que precisem de um lápis, aquele com o qual começamos a lidar nos primeiros anos de escola?

\section{Excerto 4}

A ficha caiu quando um menino de boné e cordão prata veio até mim e falou: "Professora, você fala que eu tenho que estudar. $\mathrm{O}$ que seria exatamente isso? Eu não quero perder essa oportunidade. Me ajuda..."

Esse menino mal sabia pegar no lápis por falta de hábito...

Fonte: Print de texto postado no Facebook no dia 30/04/2016 às $14: 27 \mathrm{~h}$

Talvez a resposta esteja no próprio texto, quando o cotista é associado a adereços que, segundo uma visão hegemônica, fazem parte da periferia, ou mesmo da marginalidade: "um menino de boné e cordão prata" (Excerto 4).

Não esse, que quer se afastar desse outro e alcançar o lugar de um, que quer aprender a se comportar, a se expressar de forma "comum" e para isso pede ajuda à professora: "Eu não quero perder essa oportunidade. Me ajuda..." (Excerto 4).

Como última reflexão sobre o aluno cotista, lembramos que o Cefet/RJ é uma das poucas escolas técnicas federais da cidade do Rio de Janeiro, e, por esse motivo, recebe alunos de vários lugares dessa cidade, apresentando um público sempre muito diversificado. 
Dentro desse contexto, existiria apenas uma identidade de aluno cotista?

\section{Excerto 5}

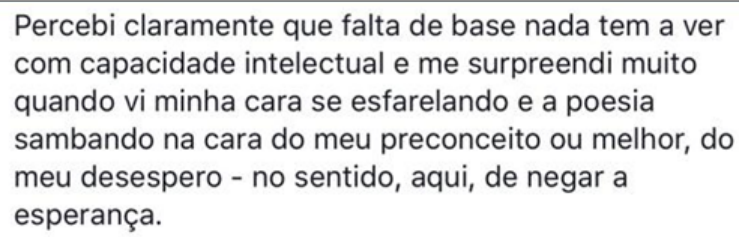

Fonte: Print de texto postado no Facebook no dia 30/04/2016 às 14:27h

O enunciado marca um processo de transição, por meio de uma descrição que funciona analogamente à uma negação polêmica (DUCROT, 1987), tensionando dois discursos, a partir de uma percepção do sujeito: "percebi claramente" (Excerto 5) que rompe com um posicionamento anterior, o de que a falta de base teria uma correlação com a capacidade intelectual - um discurso recorrente no racismo científico do início século XX (GUIMARÃES, 2009) -, e da percepção do próprio preconceito, que é atenuado ao ser reformulado no texto, como desespero. Do ponto de vista de um discurso de fato antirracista, tal mudança de percepção seria fundamental, mas não chega a se efetivar discursivamente no texto, uma vez que é desmontada por enunciados racistas ao longo do mesmo. Passemos ao Excerto 6:

\section{Excerto 6}

Tivemos que lidar também com tensões e preconceitos que existiam entre eles. Por exemplo, alguns alunos que vieram de escolas particulares com família bem estruturada não entendiam por quê o colega não fazia o trabalho direito. Inicialmente, houve, em algumas turmas, segregação. No jogo de xadrez, por exemplo, onde temos peças pretas e brancas, eles perguntavam quem seria os cotistas e os não-cotistas...

Fonte: Print de texto postado no Facebook no dia 30/04/2016 às $14: 27 \mathrm{~h}$

Quando o enunciador opõe a designação "alguns alunos que vieram de escolas particulares com família bem estruturada" (Excerto 6) ao colega que "não fazia o trabalho direito" há um não-dito subentendido que esses alunos que não fazem o trabalho direito os cotistas ou pelo menos parte deles, são oriundos de famílias desestruturadas e de escolas públicas. Ao recorrer designações cujos referentes são discursivamente vagos, isto é, dialogam com discursos conservadores, o enunciador-professora coloca em cena um racismo relativamente sutil. Desse, pode-se questionar o que está subentendido: o que seria uma família estruturada? Há uma fórmula para isso? Estudar em escola particular seria garantia dessa "família bem estruturada"? E esses dois fatores garantiriam o saber-fazer-o-trabalho-direito? Passemos ao Excerto 7, com mais uma sequência do relato:

\section{Excerto 7}

Este ano (como em outros nas minhas turmas do primeiro ano), minha primeira avaliação foi coletiva e não individual. Os alunos tinham que fazer um grupo, estudar entre eles e, no dia da prova, eu faria uma pergunta em que somente um deles, sorteado por mim na hora, resolveria no quadro a questão por mim colocada. A nota do aluno escolhido seria a nota de todos os demais componentes daquele grupo. Essa foi uma forma que encontrei de forçar os alunos privilegiados a me ajudarem a ajudar os menos privilegiados.

Fonte: Print de texto postado no Facebook no dia 30/04/2016 às $14: 27 \mathrm{~h}$

Outra marca recorrente no discurso da professora é o uso do verbo ajudar que nos remete ao campo da assistência. $\mathrm{O}$ aluno-cotista precisa ser assistido, ajudado, não só pela docente e pela equipe de apoio à qual já nos referimos, mas também pelos colegas não cotistas, de famílias bem estruturadas. E existe um motivo que justifica esse assistencialismo: "esse ser já tinha sofrido na pele o diabo da exclusão social e se sentia amedrontado perante os demais" (excerto 8).

\section{Excerto 8}

um chamado comum porque esse ser já tinha sofrido na pele o diabo da exclusão social e se sentia amedrontado perante os demais. "Você vai ser o diferencial na vida dele. Dependendo da forma em que se chegue a ele, você pode despertar um artista, um sábio, um colega pensante ou minar qualquer coisa boa que possa emergir." A menina de 15 anos me olhou assustada. Nunca talvez ninguém havia lhe dado tanta responsabilidade. Continuei: "Sim. Temos que, acima de tudo, cuidar uns dos outros sempre. Isso se aprende também na escola."

Fonte: Print de texto postado no Facebook no dia 30/04/2016 às $14: 27 \mathrm{~h}$

Quando a docente diz ao aluno regular: "Você vai ser o diferencial na vida dele. Dependendo da forma em que se chegue a ele, você pode despertar um artista, um sábio, um colega pensante ou minar qualquer coisa boa que possa emergir." (Excerto 8) outorga ao aluno não-cotista o poder de intervir, de decidir aquilo o que o aluno que ingressou pelas cotas pode chegar a ser. Pensamento que, de certa forma, dialoga com Foucault, para quem o racismo surge do dispositivo de saber/poder médico-psiquiátricojudiciário que identifica e rechaça perversos, degenerados 
e anormais, cujos corpos e comportamentos, ameaçariam a pureza de uma "raça superior" (FOUCAULT, 2002). $\mathrm{O}$ referido pensamento é reforçado pelo enunciado no Excerto 9.

\section{Excerto 9}

Ao final da aula, a aluna veio emocionada falar comigo: "Professora, fiz o que a senhora falou. Chamei o menino de outra forma e com jeitinho fui tirando dele o que ele sabia e mostrando a ele como agir. Estudamos a tarde toda. Você viu como ele falou bem?". Havia o orgulho e a felicidade em ter ajudado o próximo e incluir um que, em outra época, seria completamente jogado às margens da nossa sociedade sendo o que chamamos de "marginal" em sua essência.

Fonte: Print de texto postado no Facebook no dia 30/04/2016 às $14: 27 \mathrm{~h}$

Ao final, consoante com um pensamento meritocrático, o aluno não cotista é construído como o responsável por quaisquer conquistas do aluno-cotista.

Apresentamos, ora, um resumo das análises realizadas. No que se refere ao ethos mobilizado pelo recurso a enunciados descritivos, designações, dêixis enunciativa e subentendidos, o enunciador-professora constróise discursivamente como pessoa branca, de família estruturada e que sempre soube como estudar. Produz um fiador benfeitor, alguém que superou sua dificuldade de aceitação do outro para tornar-se testemunha do desabrochar do cidadão, e que tem o dever moral de levar esse relato a outros, ganhar adesão ao posicionamento pró-cotas, apresentando como recompensa a sensação de bem-estar oriunda da ajuda ao próximo necessitado, de um tipo de caridade ou de salvação.

O coenunciador construído no texto, que em função do gênero discursivo mobilizado, chamamos anteriormente de seguidores, parece pertencer ao mesmo mundo do enunciador e dos "alunos privilegiados". Por adesão ao discurso, constitui parte de uma comunidade que sustenta uma visão estereotipada do aluno negro, construído no texto pela identidade de cotista.

O cotista é objetificado na maior parte do texto, construído como aquele se veste e se expressa diferente, que não sabe estudar ou sequer pegar em um lápis e que é dependente de uma intervenção do outro - realizada pelos colegas privilegiados e pela professora - para "despertar como artista, sábio ou colega pensante", sem a qual, está fadado à marginalidade.

Em síntese, a identificação da construção de um ethos racista no texto em análise dá-se principalmente por meio do processo de alteridade, isto é, pelo que o enunciadorprofessora diz sobre seus alunos cotistas. É preciso ainda explicitar que tal ethos não se caracteriza para todos os interlocutores do mesmo modo, uma vez que o racismo, no contexto brasileiro, não costuma ser assumido enquanto tal e o estereótipo tipicamente associado ao racista seria um sujeito muito mais agressivo. No entanto, ao inferiorizar discursivamente os sujeitos alunos cotistas, identificados por uma corporalidade negra, um certo modo de vestir-se que os aproxima de um estereótipo ligado às culturas periféricas (boné e cordão de prata) e uma personalidade representada por uma limitação (não sabia o que era "estudar"), o enunciador constróise como superior e é por essa posição de superioridade, que se pode compreendê-lo como racista. Outro aspecto constitutivo da cena enunciativa que sustenta e é sustentada por tal ethos, é a construção de um fiador salvador, que ao identificar as 'limitações' do aluno cotista, colocase como benfeitor, apagando qualquer possibilidade de agência desse sujeito. Essa figura salvadora ainda agrega em si uma identidade de guia moral que ensina os alunos não cotistas, essencialmente privilegiados, a praticarem a 'compaixão' com o outro inferior.

\section{Considerações finais}

Propusemo-nos, neste artigo, a problematizar sentidos que se constroem na tensão entre discursos racistas e antirracistas, desde uma proposta de análise discursiva de texto que suscitou, em um segundo momento de circulação, polêmica nas mídias tradicionais e nas redes sociais, que se dividiram, defendendo e atacando a autora: racista ou não?

O ethos construído exalta a figura de uma professora que, "capaz de identificar as debilidades inerentes daqueles alunos cotistas", pode superar suas próprias dificuldades para assim poder ajudá-los, salvá-los de um destino ligado à marginalidade, sorte certa daqueles que não conseguiram essa salvação.

Reforça essa necessidade de redenção, um discurso perverso que caracteriza o aluno negro que entrou por reserva de vagas com atributos apenas negativos. Não é preciso ser professor por muitos anos para saber que sempre há, em qualquer perfil de cor ou classe, aquele aluno que não assume as responsabilidades num trabalho em grupo. A questão aqui reflete as patologias descritas por Fanon (2008). O autor responde às acusações de "complexo de inferioridade", com a qual o povo negro é taxado, com a proposta de um "complexo de autoridade" por parte dos brancos. Segundo assevera Mbembe (2014), existe, nos contextos de herança colonial, uma espécie de pacto entre os brancos de um "não-falar-a-respeito" que reforça a manutenção de privilégios e de opressões. Pouco importa se os negros são africanos ou não; a questão não é a origem, mas os objetos de discurso e de conhecimento ligados ao negro desde o início da era moderna, que 
o aprisionam ao estatuto e à função de um signo e de uma representação negativa (MBEMBE, 2014). Seguem sendo reiteradas imagens discursivas de que o negro é inferior, perigoso, menos inteligente, mais ingênuo, mais agressivo e mais potente física e sexualmente. É essa inferioridade que se materializa em discursos que se apresentam aparentemente como inocentes e antirracistas.

À guisa de conclusão, é preciso ainda reafirmar que todo significante identitário (raça, gênero, sexualidade etc.), como elemento de discurso, está sujeito à história, à mudança e à intervenção política. Dessa forma - ainda que sob condições de segregação, violência e terror racial - há um espaço para os negros, como agentes da própria história. Reinventando sua própria subjetividade, num ato de intervenção moral que possibilite a produção de outras identidades forjadas na luta e na resistência, através de práticas discursivas diversas, especialmente aquelas nos campos político, acadêmico, jurídico, midiático e cultural, que as cotas vêm ajudando a construir.

\section{Referências}

BAKHTIN, Mikhail. Estética da criação verbal. São Paulo: Martins Fontes, 2000.

DAMATTA, Roberto. Notas sobre o racismo à brasileira. In: SOUZA, Jessé (org.). Multiculturalismo e racismo: uma comparação Brasil-Estados Unidos. Brasília: Paralelo 15, 1997. p. 69-76.

DUCROT, Oswald. O dizer e o dito. Campinas: Pontes, 1987.

FANON, Frantz. Pele negra máscaras brancas. Bahia: Editora Edufba, 2008.

FOUCAULT, Michel. A arqueologia do saber. Rio de Janeiro: Forense Universitária, 2008.

FOUCAULT, Michel. Em defesa da sociedade: curso no Collège de France (1975-1976). São Paulo: Martins Fontes, 2002.

FOUCAULT, Michel. A ordem do discurso. 19. ed. São Paulo: Loyola, 2009.

GUIMARÃES, Antonio Sérgio Alfredo; RIOS, Flavia M. Cotas nas universidades públicas. Afro-Ásia, Salvador, n. 50, p. 251-256, dez. 2014. Disponível em: http://www. scielo.br/scielo.php?script=sci_arttext\&pid=S000205912014000200251\&lng=en\&nrm=iso. Acesso em: 15 maio 2018. http://dx.doi.org/10.1590/0002-05912014v50ant251

GUIMARÃES, Antonio Sérgio Alfredo. Depois da democracia racial. Tempo soc., São Paulo, v. 18, n. 2, p. 269287, nov. 2006. Disponível em: http://www.scielo.br/scielo. php?script=sci_arttext\&pid=S0103-20702006000200014\&ln $\mathrm{g}=\mathrm{en} \& \mathrm{nrm}=$ iso. Acesso em: 15 maio 2018. http://dx.doi. org/10.1590/S0103-20702006000200014
GUIMARÃES, Antonio Sérgio Alfredo. Racismo e antirracismo no Brasil. São Paulo: Editora 34, 2009.

HALL, Stuart. A identidade cultural na pós-modernidade. Rio de Janeiro: Lamparina, 2014.

HALL, Stuart. Da Diáspora. Identidades e Mediações Culturais. Organização Liv Sovik. Belo Horizonte: Editora da UFMG, 2003.

HALL, Stuart. Quem precisa da identidade? In: SILVA, Tomaz Tadeu da (Org.). Identidade e diferença. A perspectiva dos Estudos Culturais. Petrópolis, RJ: Vozes, 2009. p. 103-133.

HALL, Stuart. Raça, o significante flutuante. Z Cultural, Revista do Programa Avançado de Cultura Contemporânea, ano VIII, n. 2, 2015.

KOMESU, Fabiana. Entre o público e o privado: um jogo enunciativo na constituição do escrevente de blogs da Internet. 2005. 271p. Tese (Doutorado em Linguística) - Instituto de Estudos da Linguagem, Universidade Estadual de Campinas, Campinas.

MAINGUENEAU, Dominique. Análise de textos de comunicação. 6. ed. ampl. São Paulo: Cortez, 2013.

MAINGUENEAU, Dominique. Cenas da enunciação. Curitiba, PR: Criar Edições, 2006.

MAINGUENEAU, Dominique. Gênese dos discursos. São Paulo: Parábola Editorial, 2008.

MAINGUENEAU, Dominique. Novas tendências em análise do discurso. 3. ed. Campinas, SP: Pontes: Editora da UNICAMP, 1997.

MAINGUENEAU, Dominique. Ethos, cenografia, incorporação. In: AMOSSY, R. (org.). Imagens de Si no Discurso. A Construção do Ethos. São Paulo: Contexto, 2005 .

MBEMBE, Achile. Crítica da Razão Negra. Lisboa: Antígona, 2014.

MOITA LOPES, Luiz Paulo da (Org.). Por uma linguística aplicada indisciplinar. São Paulo: Parábola Editorial, 2006.

MOITA LOPES, Luiz Paulo da. Linguística Aplicada como lugar de construir verdades contingentes: sexualidades, ética e política. Gragoatá, n. 27, p. 33-50, 2 sem. 2009. Disponível em: http://www.uff.br/revista gragoata/revistas/gragoata27web.pdf. Acesso em: 25 mar. 2018.

MUNANGA, Kabengele. Políticas de ação afirmativa em benefício da população negra no Brasil: um ponto de vista em defesa de cotas. Sociedade e Cultura, v. 4, p. 31-43, jul.-dez. 2001. Disponível em: http://www.redalyc.org/articulo.oa? id=70311216002. Acesso em: 25 mar. 2018. 
PASSOS, Ana Helena Itamar; MIRANDA, Cláudia. Estudos críticos da branquitude e educação afrocentrada: novos aportes para uma educação antirracista. Anais do XI Congresso Luso Afro-brasileiro de Ciências Sociais.

Salvador, UFBA, 2011.

PIOVESAN, Flávia. Ações afirmativas no brasil: desafios e perspectivas. Estudos Feministas, v. 16, n. 3, p. 887-896, set.-dez. 2008.

ROCHA, Décio. Representação e intervenção: produção de subjetividade na linguagem. Gragoatá (UFF), v. 21, p. 355-372, 2006.
SANTOS, Adilson Pereira dos. Itinerário das ações afirmativas no ensino superior público brasileiro: dos ecos de Durban à Lei das Cotas. Revista de C. Humanas, Viçosa, v. 12, n. 2, p. 289-317, jul./dez. 2012.

SCHUCMAN, Lia. Vainer Entre o encardido, o branco e o branquíssimo: branquitude, hierarquia e poder na cidade de São Paulo. São Paulo: Annablume, 2013.

SOVIK, Liv. Aqui ninguém é branco: hegemonia branca e media no Brasil. In: WARE, Vron (org.). Branquidade: identidade branca e multiculturalismo. Rio de Janeiro: Garamond, 2004. p.363-386.

\section{ANEXO \\ (Texto postado no Facebook no dia 30/04/2016)}

"Há quatro anos, tivemos no CEFET/RJ nossos primeiros alunos cotistas. Para entrar lá, os jovens fazem uma prova de seleção. Naquele ano, $50 \%$ das vagas foram destinadas para alunos negros, de escolas públicas e com renda baixa.

Lembro-me que levei um susto ao entrar em sala. Havia negros e alunos extremamente diferentes na forma de se expressar. Eu simplesmente não sabia como lidar. Pensei em escrever uma carta para Dilma reclamando. Se esse governo quer colocar cotistas em sala, que ao menos nos dê uma certa infra-estrutura para recebê-los! Psicólogos, pedagogos, assistentes sociais... cadê esse time para nos ajudar? Nada? Como assim?

Da mesma forma que sempre fazia com a minha turma, eu mandava o meu aluno estudar. Dizia que se ele não fizesse a parte dele, não passaria porque bababá bububú... muitos alunos cotistas não mexiam o dedo mesmo eu repetindo o discurso: você tem que estudar! Você tem que estudar!!!

Percebi que muitos não sabiam o que era "estudar" porque, meodeos, nunca haviam estudado. Era como eu virar para qualquer outro na rua que nunca, por exemplo, estudou música e falar: você tem que treinar piano! Você tem que treinar piano! O cara ia sentar em frente ao piano e fazer o quê? Não saberia nem por onde começar! Quando percebi isso entrei em desespero porque o problema era muito maior do que pensava...

O que fazer? Desistir? Deixar que todos repetissem? Mas seriam muitos! O desespero une os seres humanos que estão sob o mesmo inferno. Nós, professores, fomos conversando e juntamente com parte da equipe pedagógica, criando subsídios para esses alunos.

A ficha caiu quando um menino de boné e cordão prata veio até mim e falou: "Professora, você fala que eu tenho que estudar. O que seria exatamente isso? Eu não quero perder essa oportunidade. Me ajuda..."

Esse menino mal sabia pegar no lápis por falta de hábito...

Tivemos que lidar também com tensões e preconceitos que existiam entre eles. Por exemplo, alguns alunos que vieram de escolas particulares com família bem estruturada não entendiam por quê o colega não fazia o trabalho direito. Inicialmente, houve, em algumas turmas, segregação. No jogo de xadrez, por exemplo, onde temos peças pretas e brancas, eles perguntavam quem seria os cotistas e os não-cotistas...

Sei que criamos aulas de atendimento... preparamos nossos monitores para atender a esse novo perfil de aluno. Ensinei a aluno segurar no lápis e organizar o raciocínio para aprender física e fazer problemas de IME e ITA como fazia em todos os outros anos e dá-lhe conversas com todos os demais privilegiados para entender que não é excluindo que incluímos ninguém. Não é fazendo o mal que faremos um bem...

O que nenhum professor do CEFET admitia era baixar o nível de nossa instituição. Eles, os alunos cotistas, teriam que alcançar os demais. Foi preciso muita dedicação, hora extra, mais avaliações para o aluno ter oportunidade de recuperar a nota - dentre outras coisas maiores como, por exemplo, amor ao próximo e empatia à causa - para que o equilíbrio, enfim, fosse alcançado.

Foi preciso muito mais trabalho...

Fizemos um forte levantamento sobre o rendimento desses alunos. Quanta emoção ver as notas deles no segundo semestre se igualando aos demais colegas que tiveram muito mais oportunidades e condições para estudar. Quanta emoção... conseguimos, gente, conseguimos... estamos conseguindo... 
Percebi claramente que falta de base nada tem a ver com capacidade intelectual e me surpreendi muito quando vi minha cara se esfarelando e a poesia sambando na cara do meu preconceito ou melhor, do meu desespero - no sentido, aqui, de negar a esperança.

Este ano (como em outros nas minhas turmas do primeiro ano), minha primeira avaliação foi coletiva e não individual. Os alunos tinham que fazer um grupo, estudar entre eles e, no dia da prova, eu faria uma pergunta em que somente um deles, sorteado por mim na hora, resolveria no quadro a questão por mim colocada. A nota do aluno escolhido seria a nota de todos os demais componentes daquele grupo. Essa foi uma forma que encontrei de forçar os alunos privilegiados a me ajudarem a ajudar os menos privilegiados.

Para um jovem de 15 anos, isso beirou o absurdo das injustiças. Uma aluna veio falar comigo: "professora, eu vou ter que convencer o outro a estudar como? Eu tô chamando e ele, quando vem, nada fala!"

Com muito amor e já mais experiente e segura, expliquei a ela que estávamos lidando com uma pessoa que vinha de uma realidade completamente diferente e que a forma de incluí-la não seria fazendo um chamado comum porque esse ser já tinha sofrido na pele o diabo da exclusão social e se sentia amedrontado perante os demais. "Você vai ser o diferencial na vida dele. Dependendo da forma em que se chegue a ele, você pode despertar um artista, um sábio, um colega pensante ou minar qualquer coisa boa que possa emergir." A menina de 15 anos me olhou assustada. Nunca talvez ninguém havia Ihe dado tanta responsabilidade. Continuei: "Sim. Temos que, acima de tudo, cuidar uns dos outros sempre. Isso se aprende também na escola."

A prova foi ontem. Sem querer, escolhi o aluno com maior dificuldade. Ele foi ao quadro e falou com certa timidez natural, mas com uma segurança que eu mesma não esperava.

Ao final da aula, a aluna veio emocionada falar comigo: "Professora, fiz o que a senhora falou. Chamei o menino de outra forma e com jeitinho fui tirando dele o que ele sabia e mostrando a ele como agir. Estudamos a tarde toda. Você viu como ele falou bem?". Havia o orgulho e a felicidade em ter ajudado o próximo e incluir um que, em outra época, seria completamente jogado às margens da nossa sociedade sendo o que chamamos de "marginal" em sua essência.

Escrevo isso sob uma emoção ainda muito forte. Quando vejo a primeira turma de cotistas se formando com louvor sem nada mais ter do que se envergonhar em termos de conhecimento em relação aos seus colegas, eu devo agradecer por essa oportunidade que esse governo me deu de fazer com que eu fosse uma verdadeira educadora. Devo agradecer pela oportunidade de me fazer unir e dialogar com os colegas e crescermos todos como um verdadeiro centro de ensino. Devo agradecer por ter me feito um ser humano infinitamente mais sensivel e melhor.

Reclama da política das cotas quem nunca sentiu na pele e testemunhou o desabrochar da dignidade de um cidadão..."

Fonte: https://www.passeiweb.com/vestibular/faculdades/rj/cefet

Recebido em: 19/09/2019

Aprovado em: 31/10/2019

Publicado em: 30/11/2019

Autores:

Bianca Assis Oliveira de Paula

Professora, Secretaria Municipal de Educação, Rio de Janeiro, Rio de Janeiro, Brasil

Orcid: https://orcid.org/0000-0002-5580-3607

E-mail: biancaaodepaula@gmail.com

Endereço: Secretaria Municipal de Educação (SME)

Av. Maracanã, 229 - Maracanã

20271-110, Rio de Janeiro, RJ, Brasil

Fabio Sampaio de Almeida

Professor, Centro Federal de Educação Tecnológica Celso Suckow da Fonseca, Rio de Janeiro, Rio de Janeiro, Brasil.

Orcid: https://orcid.org/0000-0002-1710-352X

E-mail: fabio.almeida@cefet-rj.br

Maria Cristina Giorgi

Professora, Centro Federal de Educação Tecnológica Celso Suckow da Fonseca, Rio de Janeiro, Rio de Janeiro, Brasil.

Orcid: https://orcid.org/0000-0001-5347-6115

E-mail: cristinagiorgi@terra.com.br

Endereço: Centro Federal de Educação Tecnológica Celso Suckow da Fonseca (Cefet/RJ)

Rua Afonso Cavalcanti, 455, sala 301, 3ㅇandar-Cidade Nova

20211-110, Rio de Janeiro, RJ, Brasil 